\title{
Fungsi Sosial Baitul Maal Wa Tamwil (BMT) Pasca UU No 1 Tahun 2013 tentang Lembaga Keuangan Mikro
}

\author{
Ainul Yaqin \\ UIN Prof. K. H. Saifuddin Zuhri Purwokerto, Indonesia \\ email: ainulyaqin@iainpurwokerto.ac.id
}

Manuscript History:

Received: 05-09-2021

Accepted: 04-11-2021

Published: 05-11-2021

\begin{abstract}
Baitul Maal Wa Tamwil (BMT) is one of the Islamic financial institutions that has an important role in Indonesia. From the initial concept which was later carried into its name, BMT has two functions at once, namely a business function as financial institutions in general and a social function that manages community social funds. Law No. 1 of 2013 concerning Microfinance Institutions includes $B M T$ as one of the MFIs that must comply with these rules. These regulations certainly have an impact on the social functions carried out by BMTs. This study examines how the provisions in the MFI Law and their impact on the social functions carried out by BMTs. This research is a field research with a descriptive analysis approach located at BMT Dana Mentari Mubammadiyab Purwokerto. The result of this research is that there are several provisions in the MFI Law that are related to the social function of the BMT itself, namely in terms of the status of the BMT itself, overlapping supervision that supervises, separation of social fund management, and business areas. The impact felt after the MFI Law was the separation of social funds in separate divisions that were parented by other institutions, the complexity of reporting to the institutions that overshadowed them, and difficulties in developing their social functions due to the public image that $B M T$ is just a commercial financial institution like others.
\end{abstract}

Keywords: bmt; microfinance institutions; islamic financial institution; social function

\begin{abstract}
Abstrak
Baitul Maal Wa Tamwil (BMT) merupakan salah satu lembaga keuangan syariah yang memiliki peran cukup penting di Indonesia. Dari konsep awal yang kemudian diusung menjadi namanya, BMT memiliki dua fungsi sekaligus yakni fungsi bisnis sebagaimana lembaga keuangan pada umumnya dan fungsi sosial yang mengelola dana sosial kemasyaraktan. Undang-Undang No 1 Tahun 2013 tentang Lembaga Keuangan Mikro memasukkan BMT sebagai salah satu bagian dari LKM yang harus tunduk pada aturan tersebut. Aturan tersebut tentu memiliki implikasi terhadap fungsi sosial yang dijalankan oleh BMT. Penelitian ini bermaksud meneliti bagaimana ketentuan dalam UU LKM tersebut dan pengaruhnya terhadap fungsi sosial yang dijalankan oleh BMT. Penelitian ini merupakan penelitian lapangan dengan pendekatan deskriptif analisis yang berlokasi di BMT Dana Mentari Muhammadiyah Purwokerto. Hasil dari penelelitian ini adalah bahwa ada beberapa ketentuan dalam UU LKM yang etrkait dengan fungsi sosial BMT yakni dalam hal status BMT itu sendiri, tumpang tindih
\end{abstract}


lembaga yang mengawasi, pemisahan pengelolaan dana sosial, dan pembatasan wilayah usaha. Pengaruh yang dirasakan pasca UU LKM yakni adanya pemisahan pengelolaan dana sosial dalam divisi terpisah yang menginduk pada lembaga lain, adanya kerumitan dalam pelaporan kepada lembaga yang menaungi, serta kesulitan dalam mengembangkan fungsi sosialnya akibat adanya image masyarakat bahwa BMT hanyalah lembaga keuangan komersial sebagaimana lainnya.

Kata Kunci: bmt; lembaga keuangan mikro; lembaga keuangan syariah; fungsi sosial

\section{PENDAHULUAN}

Perkembangan lembaga-lembaga keuangan syariah di Indonesia tergolong sangat pesat. Salah satu alasannya ialah karena adanya keyakinan di kalangan masyarakat muslim bahwa perbankan konvensional mengandung unsur riba yang dilarang oleh agama Islam. Di samping itu, sistem ekonomi Islam dipandang lebih lebih sedikit resiko dan lebih menjanjikan kesejahteraan bagi masyarakat. Salah satu lembaga yang patut diperhitungkan adalah BMT.

Baitul Maal Wa Tamwil yang biasa disingkat menjadi BMT merupakan sebuah lembaga keuangan yang berupaya mengembangkan usaha-usaha produktif dan investasi dalam meningkatkan kualitas kegiatan ekonomi pengusaha menengah kebawah menjalankan fungsi sosial sebagai penerima dan penyalur dana zakat, infaq dan sedekah dan menjalankannya dengan peraturan dan amanahnya (Yunus, 2009).

Kehadiran BMT memiliki peran besar dalam menyerap aspirasi masyarakat muslim di tengah kegelisahan kegiatan ekonomi dengan prinsip riba, sekaligus sebagai supporting funding untuk mengembangkan kegiatan pemberdayaan usaha kecil dan menengah. Kehadiran lembaga keuangan mikro syariah ini dirasakan telah membawa manfaat finansil bagi masyarakat, terutama masyarakat kecil yang sulit atau kurang cocok menggunakan jasa perbankan.

Kehadiran BMT di satu sisi menjalankan misi ekonomi syariah dan di sisi lain mengemban tugas ekonomi kerakyatan dengan meningkatkan ekonomi mikro, itulah sebabnya perkembangan BMT sangat pesat di tengah perkembangan lembaga keuangan mkro konvensional lainnya.

BMT merupakan gabungan dari dua fungsi, yaitu baitul maal atau rumah dana serta baitul tamwil atau rumah usaha. Baitul maal telah dikembangkan sejak zaman Nabi Muhammad SAW sebagai lembaga yang bertugas untuk mengumpulkan sekaligus membagikan (tasharuf) dana sosial, seperti zakat, infak dan sedekah (ZIS). Sedangkan baitul tamwil merupakan lembaga bisnis keuangan yang berorientasi pada laba atau keuntungan (Ridwan, 2004).

BMT memiliki karakteristik yang khas jika dibandingkan dengan lembaga keuangan lain yang ada, karena selain memiliki misi komersial (Baitut Tamwil) juga memiliki misi sosial (Baitul Maal), oleh karenanya BMT bisa dikatakan sebagai jenis lembaga keuangan mikro baru dari yang telah ada sebelumnya. Beberapa BMT mengambil bentuk hukum koperasi, namun hal ini masih bersifat pilihan, bukan keharusan. Pada awal perkembangannya, BMT dapat 
didirikan dalam bentuk Kelompok Swadaya Masyarakat (KSM) ataupun dapat juga berbentuk badan hukum koperasi. Sebelum menjalankan usahanya, KSM harus mendapatkan sertifikat dari PINBUK dan PINBUK harus mendapatkan pengakuan dari Bank Indonesia sebagai Lembaga Pengembang Swadaya Masyarakat (LPSM) yang mendukung Program Proyek Hubungan Bank dengan Kelompok Swadaya Masyarakat yang dikelola oleh Bank Indonesia (PHBK-BI) (Rohmah, 2014).

Perkembangan regulasi yang mengatur legalitas kelembagaan dan operasional BMT terbilang lambat. Hingga saat ini, belum ada aturan hukum yang secara khusus mengatur tentang BMT. Pada awal lahirnya, BMT memilih badan hukum koperasi sebagai badan hukumnya dan sering disebut dengan koperasi jasa keuangan syariah (KJKS). Oleh karena itu BMT tunduk pada aturan perkoperasian, yaitu Undang-Undang No.25 Tahun 1992 tentang Koperasi dan KEPMEN Nomor 91/KEP/M.KUKM/IX/2004 tentang Petunjuk Pelaksanaan Kegiatan Usaha Koperasi Jasa Keuangan Syariah (KJKS). Aturan hukum tersebut selanjutnya dijabarkan dalam Petunjuk Pelaksanaan (JUKLAK) dan Petunjuk Teknis (JUKNIS) serta Standar Operasional Prosedur (SOP) dan Standar Operasional Menejemen (SOM) yang tunduk pada PERMEN Nomor 352/PER/M.KUKM/X/2007 tentang Pedoman standar Operasional Manajemen Koperasi Jasa Keuangan Syariah dan Unit Usaha Jasa Keuangan Syariah (Salman, 2012).

Aturan hukum tentang Koperasi tersebut dipandang belum cukup sebagai paying hukum BMT. BMT butuh aturan hukum khusus yang mengaturnya (Murdiana, 2016). Hingga akhirnya lahirlah Undang-Undang No. 1 Tahun 2013 tentang Lembaga Keuangan Mikro. Setelah berlakunya Undang-Undang tersebut, maka status badan hukum BMT sebagai lembaga keuangan mikro hanya dapat berbentuk koperasi atau perseroan terbatas. Bila berbentuk koperasi, maka tunduk pada Undang-Undang No. 25 Tahun 1992 tentang Perkoperasian dan pengawasan berada di bawah Kementrian Koperasi dan UKM. Dan jika berbadan hukum perseroan terbatas, maka pengawasan dilakukan Otoritas Jasa Keuangan dan tunduk pada Undang-Undang No. 21 Tahun 2011 tentang Otoritas Jasa Keuangan (Salman, 2012).

Dilematika yang dialami BMT adalah permasalahan eksistensinya apabila mengembangkan usaha melebihi satu kabupaten/kota, maka harus bertransformasi menjadi bank dan berstatus badan hukum perseroan terbatas. Permasalahan transformasi lembaga keuangan yang memiliki pengembangan di lebih dari 1 kabupaten/kota memiliki aturan yang tumpang tindih antara Undang-Undang Perkoperasian dan Undang-Undang Lembaga Keuangan Mikro. Dalam hal pengawasan, lembaga keuangan mikro diawasi dan dibina oleh tiga kementerian, yaitu Otoritas Jasa Keuangan (OJK), Kementrian Koperasi dan UKM dan Kementerian Dalam Negeri, sebagaimana nota kesepahaman yang telah ditandatangani oleh tiga kementerian tersebut (Masyitoh, 2014).

Di samping itu, dengan lahirnya Undang-Undang nomor 1 tahun 2013, BMT statusnya merupakan lembaga keuangan yang aturan mainnya diatur sedemikian rupa di bawah 
pengawasan Otoritas Jasaa Keuangan (OJK). Label "lembaga keuangan" sedikit banyak berpengaruh terhadap kinerja BMT yang sejak awal memiliki visi dan misi bukan hanya menjadi lembaga yang bertujuan bisnis, namun juga menjadi lembaga yang menjalankan fungsi-fungsi sosial seperti pengelolaan zakat, infaq, dan sedekah.

Dalam pasal 11 ayat 1 UU LKM disebutkan bahwa kegiatan usaha LKM adalah meliputi jasa pengembangan usaha dan pemberdayaan masyarakat, baik melalui Pinjaman atau Pembiayaan dalam usaha Skala mikro kepada anggota dan masyarakat, pengelolaan Simpanan, maupun pemberian jasa konsultasi pengembangan usaha. Dalam pasal 14 dinyatakan bahwa LKM dilarang menjalankan usaha selain yang sudah ditentukan. Ketentuan tersebut terkesan membatasi wilayah kegiatan usaha BMT yang sejak awal dikonsepkan dapat menjalankan kegiatan dan sosial secara bersamaan.

Salah satu BMT yang merasakan adanya pengaruh akibat lahirnya UU LKM adalah BMT Dana Mentari Muhammadiyah Purwokerto. BMT Dana Mentari merupakan salah satu BMT di Purwokerto yang sudah berdiri laam dan memiliki beberapa kantor cabang. Di samping menjalankan usaha yang bersifat komersil, BMT dana Mentari juga menjalankan usaha sosial berupa pengumpulan dan penyaluran dana sosial dari dan kepada masyarakat luas (Mukarromah, 2019).

Berdasarkan pengakuan dari pengelolanya, ada beberapa pengaruh yang dirasakan sejak lahirnya UU LKM teruama terkait dengan fungsi sosial yang dijalankan. Beberapa di antaranya yakni masalah legalitas, manajemen pengelolaan, dan pandangan masyarakat. Ada beberapa penyesuaian yang telah dilakukan oleh BMT Dana Mentari agar sejalan dengan UU LKM meskipun masih ada hal-hal yang menjadi kekhawatiran serta kebingungan dalam menjalankan usahanya (Priatin, 2021).

Tulisan ini akan mengulas secara komprehensif ketentuan dalam Undang-Undang nomor 1 tahun 2013 dan turunannya yang terkait dengan BMT baik secara kelembagaan dan operasional sekaligus bagaimana pengaruhnya secara langsung di BMT Dana Mentari Muhamamdiyah Purwokerto.

\section{KAJIAN PUSTAKA}

\section{Perkembangan BMT dan Regulasinya}

Baitul Maal Wat Tamwil yang biasa disingkat menjadi BMT merupakan gabungan dari dua istilah, yaitu bait al-mal (بيث المال) dan bait at-tamwil (بيت التمويل). Dalam sejarah Islam, baitul mal dikenal sebagai institusi yang muncul sejak zaman Rasulullah dan berlanjut pada masa khalifah-khalifah pengganti beliau dan pada masa-masa kekhalifahan Islam setelahnya.

Secara harfiah baitul mal artinya 'rumah harta', yaitu rumah untuk menyimpan harta berupa semua jenis benda berharga yang dikumpulkan dan dimiliki. Adapun secara terminologis, baitul mal adalah lembaga atau pihak yang mempunyai tugas khusus 
mengenai segala harta umat, baik berupa pendapatan maupun pengeluaran negara (Huda, 2016). Adapun kata tamwil merupakan kata bentukan dari kata mal yang berarti pengembangan harta. Dengan demikian istilah bait at-tamwil berarti lembaga yang memiliki usaha pengembangan harta atau dalam istilah kontemporer berarti lembaga bisnis (Soemitra, 2012).

Dari pengertian tersebut dapat dipahami bahwa BMT merupakan lembaga bisnis yang memiliki tujuan mencari keuntungan sebagaimana lembaga bisnis pada umumnya dan juga memiliki peran dan fungsi sosial layaknya baitul mal dalam khazanah Islam.

Sejarah awal berdirinya BMT dapat ditelusuri sejak awal tahun 1980-an dengan didirikannya lembaga Baitut Tamwil Teknosa yang didirikan oleh mahasiswa ITB di Masjid Salman ITB. Lembaga ini sempat mengalami kejayaan meskipun pada akhirnya mengalami kemunduran. Selain Teknosa, pada tahun 1988 di Jakarta didirikan koperasi Ridho Gusti. Namun koperasi ini tidak sempat berkembang (Widodo, 1999).

Perkembangan BMT yang cukup pesat terjadi mengiringi berdirinya Bank Muamalat Indonesia yang berdiri pada tahun 1992. Pada tahun yang sama, di Jakarta muncul Baitul Mal wat Tamwil (BMT) Bina Insan Kamil yang digagas oleh tiga pemuda bernama Zainal Mutaqien, Aries Mufti, dan Istar Abadi. Lembaga keuangan nonperbankan ini mengenalkan konsep bagi hasil dalam bentuk mudharabah, murabahah, musyarakah, dan bai' bitsaman 'ajil bahkan juga sudah mengenalkan konsep qardhul hasan. Pada tahun itu juga muncul baitut tamwil di Semarang yang menggunakan prinsip yang sama dengan BMT Bina Insan Kamil (Widodo, 1999).

Di awal tahun 1995 telah tumbuh sekitar 60-an BMT hasil binaan Dompet Dhu'afa (DD) Republika yang di rintis sejak tahun 1994 dengan melaksanakan beberapa diklat. Mengingat jumlah yang cukup pesat, DD kemudian menghentikan diklat dan berkonsentrasi dalam pembinaan yang telah ada. Dalam pembinaan ini, DD menyiasati fungsi BMT ke dalam konsep triangle. Konsep ini membagi fungsi simpanan dan fungsi usaha riil ke dalam naungan batut tamwil, sedangkan fungsi sosialnya dijalankan oleh baitul mal (Widodo, 1999).

Pada tanggal 13 Maret 1995, muncul Pusat Inkubasi Bisnis dan Usaha Kecil (PINBUK) yang memiliki tujuan memberdayakan usaha-usaha kecil dan menengah. Lembaga ini berdiri di bawah naungan Yayasan Inkubasi Bisnis dan Usaha Kecil (YINBUK) dengan tokoh pendirinya adalah Ketua Ikatan Cendekiawan Muslim seIndonesia (ICMI) Prof. Dr. B.J. Habibie, Ketua Umum MUI KH. Hasan Basri dan Direktur Utama Bank Muamalat Indonesia Zainul Bahar Noor, S.E. (PKES, 2013).

PINBUK didirikan karena adanya tuntutan yang cukup kuat dari masyarakat yang menginginkan adanya perubahan dalam struktur ekonomi masyarakat yang dikuasai oleh beberapa gelintir golongan tertentu, utamanya dari ekonomi konglomerasi kepada ekonomi yang berbasis masyarakat banyak. Strategi PINBUK juga menggunakan BMT sebagai lini terdepan. Setelah belajar dari BMT Bina Insan Kamil, Pinbuk dengan agresif 
menyelenggarakan diklat BMT di berbagai daerah. Dalam periode dasawarsa pertama 1995-2005 PINBUK berhasil memfasilitasi penumbuhkembangan lebih dari 3.000 BMT di seluruh Indonesia.

Dalam peraturan perundang-undangan di Indonesia, posisi BMT sesungguhnya sudah cukup jelas, yakni BMT merupakan bagian dari lembaga keuangan mikro sebagaimana diatur dalam Undang-Undang Nomor 1 Tahun 2013 tentang Lembaga Keuangan Mikro (selanjutnya disingkat UU LKM) dan oleh karenanya diatur dan diawasi oleh Otoritas Jasa Keuangan. Hanya saja, dalam praktiknya, BMT juga dapat didirikan, dikelola, dan diawasi berdasarkan kewenangan Pemerintah Pusat, Pemerintah Daerah Provinsi, dan Pemerintah Daerah Kabupaten/Kota berdasarkan Undang-Undang Nomor 25 Tahun 1992 tentang Perkoperasian dan Peraturan Pemerintah Nomor 9 Tahun 1995 tentang Pelaksanaan Kegiatan Usaha Simpan Pinjam oleh Koperasi. Instansi pemerintah pusat yang berwenang adalah Kementerian Koperasi dan Usaha Kecil dan Menengah dan Satuan Kerja Perangkat Daerah Provinsi/Kabupaten/Kota Bidang Perkoperasian.

Otoritas Jasa Keuangan dengan Kementerian Koperasi dan Usaha Kecil dan Menengah terkait dengan perizinan dan pengawasan penyedia jasa keuangan, termasuk BMT.

Dari sini dapat dilihat bahwa BMT sebagai lembaga keuangan syariah di Indonesia terpecah menjadi kewenangan dua lembaga negara yakni:

a. BMT sebagai LKM

Dalam Undang-Undang Nomor 1 Tahun 2013 tentang Lembaga Keuangan Mikro disebutkan beberapa ketentuan di antaranya bahwa Lembaga Keuangan Mikro yang selanjutnya disingkat LKM adalah lembaga keuangan yang khusus didirikan untuk memberikan jasa pengembangan usaha dan pemberdayaan masyarakat, baik melalui pinjaman atau pembiayaan dalam usaha skala mikro kepada anggota dan masyarakat, pengelolaan simpanan, maupun pemberian jasa konsultasi pengembangan usaha yang tidak semata-mata mencari keuntungan. Dalam Pasal 9 ayat (1) dinyatakan bahwa Sebelum menjalankan kegiatan usaha, LKM harus memiliki izin usaha dari Otoritas Jasa Keuangan.

Di sisi lain, dalam Pasal 34 ayat (1) terdapat ketentuan bahwa setiap orang yang menjalankan usaha LKM tanpa izin sebagaimana dimaksud dalam Pasal 9 ayat (1), dipidana dengan pidana penjara paling singkat 1 (satu) tahun dan paling lama 3 (tiga) tahun serta pidana denda paling sedikit Rp50.000.000,00 (lima puluh juta rupiah) dan paling banyak Rp1.000.000.000,00 (satu miliar rupiah). Sementara dalam Pasal 34 ayat (2) dinyatakan bahwa dalam hal kegiatan sebagaimana dimaksud pada ayat (1) dilakukan oleh badan hukum yang berbentuk perseroan terbatas atau koperasi, maka penuntutan terhadap badan-badan dimaksud dilakukan baik terhadap mereka yang 
memberi perintah melakukan perbuatan itu atau yang bertindak sebagai pimpinan dalam perbuatan itu atau terhadap kedua-duanya.

Ketentuan-ketentuan di atas masih ditambah lagi dengan ketentuan pada Pasal 39 yang menyatakan bahwa:

1) Pada saat Undang-Undang tersebut mulai berlaku, Bank Desa, Lumbung Desa, Bank Pasar, Bank Pegawai,Badan Kredit Desa (BKD), Badan Kredit Kecamatan (BKK), Kredit Usaha Rakyat Kecil (KURK), Lembaga Perkreditan Kecamatan (LPK), Bank Karya Produksi Desa (BKPD), Badan Usaha Kredit Pedesaan (BUKP), Baitul Maal wa Tamwil (BMT), Baitul Tamwil Mubammadiyah (BTM), dan/atau lembaga-lembaga lainnya yang dipersamakan dengan itu tetap dapat beroperasi sampai dengan 1 (satu) tahun terhitung sejak Undang-Undang tersebut berlaku.

2) Lembaga-lembaga sebagaimana dimaksud pada ayat (1) wajib memperoleh izin usaha dari Otoritas Jasa Keuangan paling lama 1 (satu) tahun terhitung sejak Undang-Undang tersebut berlaku.

3) Dikecualikan dari ketentuan tersebut di atas adalah Lembaga Perkreditan Desa dan Lumbung Pitih Nagari serta lembaga sejenis yang telah ada sebelum Undang-Undang ini berlaku, dinyatakan diakui keberadaannya berdasarkan hukum adat dan tidak tunduk pada Undang-Undang ini.

Dari ketentuan-ketentuan di atas jelas terlihat bahwa Baitul Maal Wa Tamwil (BMT) diposisikan sebagai Lembaga Keuangan Mikro/LKM, yang wajib memperoleh dan memiliki izin usaha dari Otoritas Jasa Keuangan. Dalam Undangundang Nomor 1 Tahun 2013 ini ada kriminalisasi terhadap setiap orang atau badan hukum yang menjalankan usaha BMT tanpa izin dari Otoritas Jasa Keuangan.

Konsekuensi dari BMT sebagai LKM adalah kewajiban BMT untuk tunduk kepada ketentuan-ketentuan tentang Lembaga Keuangan Mikro dalam UndangUndang Nomor 1 Tahun 2013 tentang Lembaga Keuangan Mikro dan peraturan perundang-undangan pelaksanaannya. BMT, baik yang telah berbadan hukum Perseroan Terbatas atau Koperasi, maupun yang tidak berbadan hukum harus menyesuaikan bentuk kelembagaan, sistem operasional, bidang usaha, permodalan, dan seluruh aspek yang terkait dengan ketentuan-ketentuan dalam peraturan perundang-undangan yang menjadi dasar hukum bagi Otoritas Jasa Keuangan dan lembaga penegak hukum dalam melaksanakan tugas-tugas terkait Lembaga Keuangan Mikro.

b. BMT sebagai Koperasi Syariah

Dalam praktiknya, ada peraturan perundang-undangan di Indonesia selain Undang-Undang LKM yang pada saat ini juga mengatur BMT, terutama BMT yang berbadan hukum Koperasi dan memiliki izin usaha simpan pinjam. Pada saat ini, BMT tunduk kepada Undang-Undang Nomor 25 Tahun 1992 tentang Perkoperasian 
dan Peraturan Pemerintah Nomor 9 Tahun 1995 tentang Pelaksanaan Kegiatan Usaha Simpan Pinjam oleh Koperasi, serta dipertegas dengan Undang-Undang Nomor 23 Tahun 2014 tentang Pemerintahan Daerah. Undang-Undang Nomor 23 Tahun 2014 tentang Pemerintahan Daerah, Lampiran Huruf Q, mengatur:

1) Kewenangan Pemerintah Pusat untuk pemberian status badan hukum Koperasi;

2) Kewenangan Pemerintah Pusat, Pemerintah Daerah Provinsi, dan Pemerintah Kabupaten/Kota dalam menerbitkan izin usaha simpan pinjam, izin pendirian kantor cabang, kantor cabang pembantu dan kantor kas;

3) Kewenangan Pemerintah Pusat, Pemerintah Daerah Provinsi, dan Pemerintah Kabupaten/Kota dalam pengawasan dan pemeriksaan Koperasi, termasuk Koperasi yang memiliki izin usaha simpan pinjam;

4) Kewenangan Pemerintah Pusat, Pemerintah Daerah Provinsi, dan Pemerintah Kabupaten/Kota dalam penilaian kesehatan Koperasi Simpan Pinjam/Unit Simpan Pinjam Koperasi;

5) Kewenangan Pemerintah Pusat, Pemerintah Daerah Provinsi, dan Pemerintah Kabupaten/Kota dalam pendidikan dan pelatihan perkoperasian; dan

6) Kewenangan Pemerintah Pusat, Pemerintah Daerah Provinsi, dan Pemerintah Kabupaten/Kota dalam pemberdayaan dan perlindungan Koperasi.

Dalam praktiknya, BMT dapat memilih, apakah menjadi LKM menurut UndangUndang LKM atau Koperasi Simpan Pinjam/ Unit Simpan Pinjam Koperasi/Koperasi Simpan Pinjam dan Pembiayaan Syariah/Unit Simpan Pinjam dan Pembiayaan Syariah Koperasi. Ketentuan pidana yang ada dalam UndangUndang LKM, prakteknya hanya ditujukan untuk menanggulangi penyelenggaraan LKM tanpa izin sama sekali, dan tidak ditujukan kepada BMT yang menjadi Koperasi Simpan Pinjam/ Unit Simpan Pinjam Koperasi/Koperasi Simpan Pinjam dan Pembiayaan Syariah/Unit Simpan Pinjam dan Pembiayaan Syariah Koperasi.

\section{Fungsi dan Peran BMT}

BMT pada dasarnya merupakan pengembangan dari konsep ekonomi dalam Islam terutama dalam bidang keuangan. BMT menggabungkan dua kegiatan yang berbeda sifatnya, laba dan nirlaba, dalam satu lembaga. Namun secara operasional, dalam BMT dua hal tersebut tetap merupakan entitas yang terpisah (Widodo, 1999).

Fungsi BMT sebagai sebuah lembaga keuangan yang berkembang saat ini bisa dilihat dari dua istilah yang menyusunnya, yaitu:

a. Baitul Maal (Bait = Rumah, Maal = Harta) menerima titipan dana Zakat, Infaq dan Shadaqah serta mengoptimalkan distribusinya sesuai dengan peraturan dan amanahnya.

b. Baitut Tamwil (Bait $=$ Rumah, at-Tamwil = Pengembangan Harta) melakukan kegiatan pengembangan usaha-usaha produktif dan investasi dalam meningkatkan 
kualitas ekonomi pengusaha mikro dan kecil terutama dengan mendorong kegiatan menabung dan menunjang pembiayaan kegiatan ekonominya (Soemitra, 2012).

Sebagai lembaga keuangan syariah yang bergerak di sektor mikro, BMT memiliki fungsi dan peran penting untuk menunjang peningkatan ekonomi rakyat. Prinsip-prinsip BMT dapat berjalan dengan baik apabila fungsi tersebut dilaksanakan dengan tata kelola dan prosedur yang baik. Muhammad Ridwan menjelaskan ada lima fungsi yang harus dilaksanakan oleh BMT, yaitu (Ridwan, 2005):

a. Mengidentifikasi, memobilisasi, mengorganisasi, mendorong dan mengembangkan potensi serta kemampuan potensi ekonomi anggota, kelompok anggota mu'amalat (pokusma) dan daerah kerjanya.

b. Meningkatkan kualitas SDM anggota dan pokusma menjadi lebih professional dan Islami, sehingga semakin utuh dan tangguh dalam menghadapi persaingan global.

c. Menggalang dan memobilisasi potensi masyarakat dalam rangka meningkatkan kesejahteraan anggota.

d. Menjadi perantara keuangan (financial intermediary) antara agniya (orang yang punya kelebihan materi) sebagai shabibul maal, dengan du'afa (orang kekurangan materi) sebagai mudharib, terutama untuk dana-dana sosial seperti zakat, infak, sedekah, wakaf, hibah dan lain-lain.

e. Menjadi perantara keuangan (financial intermediary) antara pemilik modal (shabibul maal), baik sebagai pemodal maupun penyimpan dengan pengguna dana (mudharib) untuk pengembangan usaha produktif.

Menurut Andri Soemitra, beberapa fungsi yang dapat dijalankan oleh BMT adalah sebagai berikut (Soemitra, 2012):

a. Penghimpun dana dan penyaluran dana, dengan menyimpan uang di BMT, uang tersebut dapat ditingkatkan utilitasnya, sehingga timbul unit surplus (pihak yang memiliki dana berlebih) dan unit deficit (pihak yang kekurangan dana).

b. Pencipta dan pemberi likuiditas, dapat menciptakan alat pembayaran yang sah yang mampu memberikan kemampuan untuk memenuhi kewajiban suatu lembaga/perorangan.

c. Sumber pendapatan, BMT dapat menciptakan lapangan kerja dan memberi pendapatan kepada para pegawai.

d. Pemberi informasi, memberi informasi kepada masyarakat mengenai resiko keuntungan dan peluang yang ada pada lembaga tersebut.

e. Sebagai satu lembaga keuangan mikro Islam yang dapat memberikan pembiayaan bagi usaha kecil, mikro, menengah dan juga koperasi dengan kelebihan tidak meminta jaminan yang beratkan bagi UMKMK tersebut.

Adapun peran yang dijalankan oleh BMT dalam perekonomian antara lain sebagai berikut (Huda, 2010) 
a. Menjauhkan masyarakat dari praktik ekonomi yang bersifat non Islam. Aktif melakukan sosialisasi ditengah masyarakat tentang arti penting sistem ekonomi Islam. Hal ini bisa dilakukan dengan pelatihan-pelatihan mengenai cara-cara bertransaksi yang Islami, misalnya supaya ada bukti dalam transaksi, dilarang curang dalam menimbang barang, jujur terhadap konsumen, dan sebagainya.

b. Melakukan pembinaan dan pendanaan usaha kecil. BMT harus bersikap aktif menjalankan fungsi sebagai lembaga keuangan mikro, misalnya dengan jalan pendampingan, pembinaan, penyuluhan, dan pengawasan terhadap usaha-usaha nasabah.

c. Melepaskan ketergantungan pada rentenir, masyarakat yang masih bergantung pada rentenir disebabkan rentenir mampu memenuhi kebutuhan masyarakat dalam memenuhi dana dengan segera. Maka BMT harus mampu melayani masyarakat lebih baik, misalnya selalu tersedia dana setiap saat, birokrasi yang sederhana, dan lain sebagainya.

d. Menjaga keadilan ekonomi masyarakat dengan distribusi yang merata. Fungsi BMT langsung berhadapan dengan masyarakat yang kompleks dituntut harus pandai bersikap. Oleh karena itu langkah untuk melakukan evaluasi dalam rangka pemetaan skala prioritas yang harus diperhatikan, misalnya dalam masalah pembiayaan, BMT harus memerhatikan kelayakan usaha nasabah dalam hal golongan nasabah dan juga jenis pembiayaan yang dilakukan.

Fungsi sosial BMT yang menjadi ciri khas dibanding lembaga keuangan lain, dipersepsikan dalam beberapa bentuk sebagai berikut (Satria, 2015):

a. Pengelolaan zakat, infaq dan sedekah. Ketiganya merupakan perintah dan anjuran agama yang telah disyariatkan dengan jelas bagi umat Islam.

b. Pemberdayaan masyarakat dhuafa. Sebagai lembaga yang bergerak dibidang jasa keuangan maka lembaga keuangan mikro syariah memiliki peran dalam mencetak wirausahawan baru dari masyarakat dhuafa.

c. Dakwah dan syiar Islam. Dakwah nilai-nilai keIslaman di sini yakni lembaga keungan syariah berperan untuk memberantas praktik rentenir yang terjadi dimasyarakat khususnya pedagang kecil yang terjerat rentenir. Selain itu juga memasyarakatkan sistem ekonomi Islam di mana dalam sebuah transaksi ekonomi dijalankan sesuai dengan kaidah-kaidah prinsip syariah.

Bentuk-bentuk fungsi sosial yang dilaksanakan oleh BMT antara lain adalah penyaluran dana bantuan sosial untuk kemakmuran dan pembangunan masjid sebagai pusat dakwah Islam. Pada sisi kemakmuran masjid, diberikan bantuan dalam bentuk santunan takmir masid dan pemenuhan kebutuhan dalam mempelajari baca tulis alQuran. Bentuk fungsi sosial lainnya berupa bantuan permodalan kepada masyarakat duafa dilaksanakan dengan pinjaman tanpa bunga menggunakan akad al-qard al-hasan. Jika usaha berkembang maka ditingkatkan dengan akad qard dan selanjutnya dengan 
kerjasama bagi hasil atau jual beli. Bentuk fungsi sosial lainnya berupa optimalisasi peran BMT. Dengan banyaknnya anggota yang tersebar di beberapa daerah dapat dimaksimalkan dengan membuka cabang di daerah yang terpencil sehingga pelayanan dan dakwah Islam dapat menjangkau masyarakat yang belum dapat mengakses fasilitas lembaga keuangan khususnya lembaga keuangan syariah (Satria, 2015).

Pada dasarnya, BMT dan lembaga keuangan perbankan memiliki tujuan dan fungsi yang sama sebagai penghimpun dan penyalur pembiayaan masyarakat. Hanya saja, sebagaimana disebutkan di awal, usaha yang dijalankan oleh BMT memiliki kekhasan karena membawa nama baitul maal yang merupakan entitas yang dimaksudkan untuk mengelola dana sosial.

Sebagai baitul maal, BMT berfungsi sebagai lembaga pengemban amanag, yang menghimpun dana sosial kemudian menyalurkannya sebagai bentuk kebajikan kepada masyarakat yang membutuhkan. Sumber dananya dapat berupa zakat, infaq, sedekah, atau bentuk lain yang sah dan sesuai syariat Islam. Adapun penyalurannya, ada yang murni bersifat hibah, ada pula yang berupa pinjaman tanpa tambahan kembalian (bunga) (Amalia, 2009).

Sebagai baitut tamwil, BMT berfungsi sebagaimana lembaga keuangan lainnya yang bertujuan mencari keuntungan dengan menjalankan usaha yang bersifat komersial berupa penghimpunan dan penyaluran dana berdasakan prinsip syariah. Bentuk akad-akad yang digunakan tidak berbeda dengan bank syariah karena yang menjadi rujukan adalah aturan akad dalam Islam yang dirumuskan dalam fatwa DSN MUI (Amalia, 2009).

\section{METODE PENELITIAN}

Penelitian ini merupakan penelitian lapangan (Field Research), yaitu penelitian yang dilakukan dengan terjun langsung ke lapangan atau tempat/lokasi yang akan menjadi objek penelitian (Suryabrata, 2002). Pendekatan yang digunakan dalam penelitan ini adalah yuridis normatif. Sumber data dalam peneltian ini adalah UU Nomor 1 Tahun 2013 tentang Lembaga Keuangan Mikro dan data hasil wawancara, observasi, dan dokumentasi di lokasi. BMT yang menjadi lokasi penelitian ini adalah BMT Dana Mentari Muhammadiyah Purwokerto.

\section{HASIL DAN PEMBAHASAN}

\section{Ketentuan UU No 1 Tahun 2013 Tentang LKM dan Pengaruhnya terhadap Fungsi Sosial BMT}

Lembaga keuangan mempunyai fungsi sebagai intermediasi dalam aktifitas suatu perekonomian. Jika fungsi ini berjalan baik, maka lembaga keuangan tersebut dapat menghasilkan nilai tambah (value added). Aktifitas ekonomi disini tidak membedakan antara usaha yang dilaksanakan tersebut besar atau kecil, karena yang membedakan hanya besarnya nilai tambah berdasarkan skala usaha. Hal ini berarti bahwa usaha kecilpun jika memanfaatkan lembaga keuangan dengan baik akan memberikan kenaikan nilai tambah, 
sehingga upaya meningkatkan pendapatan masyarakat salah satunya dapat dilakukan dengan cara yang produktif, dengan memanfaatkan jasa intermediasi lembaga keuangan termasuk usaha produktif yang dilakukan oleh masyarakat miskin dan berpenghasilan sangat rendah dan rendah (Saragih, 2011).

Dari awal sejarah berdirinya, BMT merupakan lembaga keuangan yang bersifat alternatif. Hal ini terjadi karena Undang-Undang No. 7 Tahun 1992 tentang Perbankan hanya mengakui adanya dua lembaga keuangan bank, yaitu Bank Umum dan Bank Pengkreditan Rakyat (BPR). Bank umum mempunyai wilayah operasi yang cukup luas cakupannya yaitu meliputi wilayah perkotaan dan sekitarnya, sedang BPR mempunyai wilayah cakupan kecematan. Sedangkan lembaga keuangan yang beroperasi secara syariah, yaitu Bank Mu'amalat Indonesia (BMI) sebagai lembaga bank umum, dan Bank Pengkreditan Rakyat Syari'ah (BPRS).

Keberadan dua lembaga keuangan tersebut yang diakui oleh undang- undang belum dapat melayani sepenuhnya kepentingan dan kebutuhan umat. Operasionalisasi BMI kurang menjangkau usaha masyarakat kecil dan menengah. Maka atas dasar tersebut terbentuklah Baitul Maal wat Tamwil (BMT). Pembentukan ini, awalnya tidak terikat dengan peraturan pemerintah atau undang-undang sebagaimana dalam pembentukan bank umum dan bank perkreditan rakyat.

Undang-undang No.1 tahun 2013 tentang LKM secara eksplisit disebutkan bahwa BMT merupakan bagian dari lembaga keuangan mikro yang diatur dan diawasi oleh Otoritas Jasa Keuangan (OJK). Ketentuan ini termaktub dalam Pasal 39, di mana pada saat Undang-Undang ini mulai berlaku, Bank Desa, Lumbung Desa, Bank Pasar, Bank Pegawai, Badan Kredit Desa (BKD), Badan Kredit Kecamatan (BKK), Kredit Usaha Rakyat Kecil (KURK), Lembaga Perkreditan Kecamatan (LPK), Bank Karya Produksi Desa (BKPD), Badan Usaha Kredit Pedesaan (BUKP), Baitul Maal wa Tamwil (BMT), Baitul Tamwil Muhammadiyah (BTM), dan/atau lembaga-lembaga lainnya yang dipersamakan dengan itu tetap dapat beroperasi sampai dengan 1 (satu) tahun terhitung sejak Undang-Undang ini berlaku. Lembaga-lembaga keuangan mikro tersebut wajib memperoleh izin usaha dari Otoritas Jasa Keuangan. Dengan demikian, dari ketentuan Pasal tersebut, maka BMT dapat berkedudukan sebagai bagian dari Lembaga Keuangan Bukan Bank yang tergolong sebagai Lembaga Keuangan Mikro Syari’ah.

UU No 1 Tahun 2013 tentang LKM tersebut di samping membawa perubahan status BMT, juga membawa pengaruh lain terhadap aspek-aspek lain dalam BMT, salah satunya dalam fungsi sosial yang dijalankan oleh BMT. Undang-undang LKM berisi aturan terkait lembaga keuangan mikro yang sebelumnya belum diatur. Berbagai macam lembaga mikro yang sebelumnya eksis harus tunduk dalam undang-undang tersebut. Masalahnya adalah tidak semua lembaga keuangan mikro yang ada sebelumnya memiliki kesamaan. Masingmasing lembaga keuangan mikro tersebut memiliki kekhasan masing-masing. 
Di sisi lain, BMT dari namanya didirikan dengan konsep adanya keseimbangan pengelolaan antara fungsi bisnis dan sosial. Dengan adanya undang-undang tersebut, seolah menegaskan bahwa BMT hanyalah lembaga keuangan seperti lembaga keuangan lain pada umumnya. Ditambah lagi, dalam undang-undang tersebut dijelaskan usahausaha yang dapat dijalankan oleh LKM yang terbatas pada usaha bisnis semata, tidak ada ketentuan tentang usaha yang bersifat sosial.

Berdasarkan penelitian Umi Rohmah, para pelaku usaha BMT mengaku keberatan dengan dimasukkannya BMT sebagai lembaga keungan. Alasannya di antaranya BMT sebagai sebuah elemen masyarakat yang ingin diakui keberadaannya sebagai lembaga yang berbeda dari yang lainnya tentu memiliki kelompok komunitasnya tersendiri, dan BMT lebih memilih untuk tidak pada posisi dan statusnya saat ini meskipun pemerintah memasukkannya kedalam kelompok lembaga keuangan mikro sebagaimana yang telah BMT perkenalkan selama ini (Rohmah, 2014).

Penolakan BMT untuk menjadi LKM disebabkan oleh beberapa alasan. Pertama, BMT masih kesulitan menetapkan posisinya meskipun telah diberi pilihan untuk menjadi LKM syariah yang berbadan hukum koperasi. Kedua, BMT ingin menghindari sistem audit ketat yang diberlakukan oleh OJK kepada semua lembaga keuangan. Ketiga, longgarnya sistem pengawasan BMT yang dilakukan dinas koperasi, pengawas syariah dan manajemen BMT, serta PINBUK. Keempat, BMT dengan badan hukumnya yang sekarang ini tidak dikenakan pajak besar seperti pada lembaga bank. Kelima, BMT tidak ingin kehilangan jiwa kerakyatan yang selama ini menjadi semangat dan prinsip dasar dalam melakukan aktivitas-aktivitasnya baik sebagai lembaga sosial maupun komersil. Semua alasan tersebut menunjukkan bahwa BMT tetap merasa dirinya berbeda dari koperasi dan LKM, sehingga berusaha mempertahankan jati dirinya sebagai BMT sebagaimana yang telah diketahui secara umum oleh masyarakat untuk tetap menjalankan dua peran utamanya baik itu peran sosial maupun peran komersilnya (Rohmah, 2014).

BMT Dana Mentari Purwokerto sampai saat penelitian ini dilakukan mengaku belum sepenuhnya tunduk pada UU LKM. BMT Dana Mentari dengan badan hukum sebagai koperasi masih sepenuhnya bernaung pada Kementerian Koperasi, belum mendaftarkan diri pada OJK. Meskipun begitu, beberapa penyesuaian telah dilakukan kaitannya dengan pengelolaan dana sosial.

Sejak awal di dirikan, BMT Dan Mentari berbadan hukum koperasi yakni Koperasi Serba Usaha. Dalam menjalankan usahanya, BMT Dana Mentari menggunakan prinsip syariah sebagai dasar akad-akad yang dipakai. Selain menjalankan usaha bisnis, BMT Dana Mentari juga menjalankan fungsi sosial dengan mengelola dana sosial yang disalurkan kepada masyarakat (KHomsatun, 2021).

Dalam pemahaman pengelola BMT Dana Mentari, UU LKM memberikan implikasi salah satunya pemisahan pengelolaan fungsi sosial dari fungsi bisnis BMT. UU LKM dan aturan turunannya memang tidak secara eksplisit mengatur tentang usaha sosial oleh 
LKM. Bahkan ada ancaman pidana bagi LKM yang menjalankan usaha selain yang sudah ditentukan dalam UU. Hal ini menjadikan fungsi sosial BMT seolah diabaikan dan pengelola harus mencari cara lain agar kegiatan tersebut tetap berjalan.

Oleh karena itu, sejak tahun 2016 dibentuk satu divisi khusus yang mengurusi dana sosial yang diperoleh oleh BMT Dana Mentari. Divisi tersebut diberi nama Baitul Maal Dana Mentari Muhammadiyah. Uniknya, meskipun secara struktur pengelola dana sosial berada di bawah manajer umum, namun secara kelembagaan mengaku menginduk pada Lembaga Dompet Dhuafa yang memiliki legalitas sebagai lembaga pengelola zakat, infaq, dan sedekah. Alasannya mereka khawatir jika dana sosial tetap dikelola atas nama BMT akan melanggar aturan UU LKM.

"Sekarang ini untuk dana sosialnya dikelola oleh divisi khusus yang posisinya di bawah Manajer Pusat. Namun secara kelembagaan sebagai lembaga pengelola zakat bernaung di bawah Dompet Dhu'afa. Jadi semacam UPZ (Unit Pengumpulan Zakat). Ke Dompet Dhu'afa kami hanya laporan tapi pengelolaannya kami sendiri." (Priatin, 2021).

Budi Setiawan selaku Divisi Baitul Maal mengatakan bahwa sebelum berlakunya UU LKM pengelolaan dana sosial menjadi kewenangan masing-masing kantor cabang. Setelah UU LKM berlaku, baru dibuat divisi khusus untuk menjalankan fungsi sosial. Terkait prosedur penyalurannya, Budi Setiawan megatakan sebagai berikut:

"Setelah adanya UU misalkan ada proposal permohonan bantuan atau lainnya yang kaitannya dengan fungsi sosial maka akan diserahkan ke divisi mall. Namun untuk proposal bisa diajukan melalui kantor cabang dan dari kantor cabang akan diteruskan ke divisi maal." (Setiawan, 2021)

Aturan tentang usaha sosial ini jika ditelusuri sebenarnya dapat ditemukan dalam beberapa peraturan hukum. Keputusan Menteri Negara Koperasi dan Usaha Kecil dan Menengah nomor: 91/KEP/M.KUKM/IX/2004 tentang Petunjuk Pelaksanaan Kegiatan Usaha Koperasi Jasa Keuangan Syariah mengatur bahwa Koperasi Jasa Keuangan Syariah/Unit Jasa Keuangan Syariah selain menjalankan kegiatan pembiaya an atau tamwil, dapat menjalankan kegiatan maal, dan atau kegiatan pengumpulan dan penyaluran dana Zakat, Infaq, dan Sodaqoh (ZIS), termasuk wakaf.

Dalam menjalankan kegiatan sosial tersebut, ada ketentuan yang harus diperhatikan yakni sebagai berikut:

a. Dikelola dan disupervisi oleh penanggungjawab khusus.

b. Wajib memisahkan sistem administrasi dan laporan keuangan kegiatan maal-nya dengan kegiatan pembiayaan tamwilnya.

c. Kegiatan bidang maal harus mengacu pada peraturan dan perundang-undangan pengelolaan Zakat, Infaq, dan Sodaqoh (ZIS).

d. Dalam hal terjadi kesulitan pengelolaan baik karena aspek teknis maupun aspek legal, maka kegiatan maal harus dipisahkan dari kegiatan Koperasi Jasa Keuangan Syariah/Unit Jasa Keuangan Syariah, dan dikelola melalui lembaga di luar Koperasi 
Jasa Keuangan Syariah/Unit Jasa Keuangan Syariah.

Dalam Peraturan OJK Nomor 13/POJK.05/2014 Tentang Penyelenggaraan Usaha Lembaga Keuangan Mikro. Dalam pasal 13 ayat (4) dan (5) disebutkan pula bahwa LKM yang melakukan usaha berdasarkan prinsip syariah dapat melakukan pengelolaan dana sosial berupa zakat, infak, dan sodaqoh. Pembukuan atas pengelolaan dana sosial tersebut harus dilakukan secara terpisah dari aktivitas penghimpunan Simpanan dan penyaluran Pembiayaan yang merupakan kegiatan utama dari LKM yang bersangkutan.

Pengelola BMT Dana Mentari mengaku belum mengetahui terkait aturan-aturan tersebut. Alasannya karena badan hukum yang dipilih oleh BMT Dana Mentari adalah Koperasi Serba Usaha, sementara peraturan menteri dia atas mengatur tentang KJKS. Alasan lainnya karena memang sejak keluarnya UU LKM baru mendapat sosialisasi tentang UU tersebut, belum aturan lainnya. Pengelola merasa keharusan BMT tunduk pada UU LKM yang mengharuskan tunduk di bawah OJK menyebabkan kerumitan dan kerepotan dalam menjalankan usaha BMT.

"Sampai saat ini kami masih tetap di bawah Dinperindagkop baik untuk pengawasan dan pelaporan. Pelaporan di Disperindagkop lebih sederhana dan mudah. Kalau dengan OJK kami memang belum.”

Kondisi seperti dia atas agaknya dihadapi oleh BMT berbadan hukum koperasi lainnya yang sebelumnya hanya tunduk pada Kementerian Koperasi dan UKM kemudian harus juga tunduk dan melakukan pelaporan pada OJK.

Potensi dan manfaat dana sosial BMT menurut pengelola BMT Dana Mentari sebenarnya cukup besar. Dana tersebut berupa zakat, infaq, dan sedekah yang ditarik dari pengelola (pengurus dan karyawan), anggota simpanan dan anggota pembiayaan. Dalam Laporan Keuangan tahun 2020, tercantum alokasi penyalurannya juga sudah mencakup berbagai bidang seperti pendidikan, keagamaan, sosial, ekonomi,dan kesehatan. Khusus untuk dana zakat alokasinya untuk delapan kelompok (asnaf) yang berhak menerima zakat.

Dari kenyataan tersebut tampak bahwa UU LKM memiliki dampak yang besar bukan hanya pada fungsi sosial BMT tapi juga aspek lainnya yang saling berkaitan. Status BMT sebagai lembaga keuangan menurut pengelola BMT Dana Mentari juga semakin menambah anggapan masyarakat umum bahwa BMT tidak berbeda dengan lembaga keuangan lainnya yang semata-mata menjalankan bisnis.

"Dari masyarakat pun mayoritas tahunya BMT itu lembaga keuangan yang hanya melayani simpan pinjam." (Setiawan, 2021).

Hal lain dari UU LKM yang juga berpengaruh terhadap fungsi sosial yang dijalankan oleh BMT adalah masalah pembatasan wilayah operasional. Dalam pasal 16 UU LKM disebutkan bahwa cakupan wilayah usaha LKM adalah desa/kelurahan, kecamatan atau kabupaten/kota. Pembatasan ini memberikan implikasi BMT tidak dapat memperluas wilayah usahanya melebihi satu kabupaten/kota, termasuk usaha dalam bidang sosialnya. 
Pengelola BMT Dana Mentari mengaku menginginkan agar ada aturan tersendiri agar BMT dengan kekhasannya dapat menjalankan kedua fungsinya dengan seimbang.

"Kami tentunya ingin agar fungsi tamwil dan fungsi baitul mall nya berjalan dua-duanya dengan seimbang. Kalau sekarang ini agak-agak khawatir dan cukup membingungkan.” (Priatin, 2021)

Keinginan ini menjadi hal yang penting direalisaikan dengan dukungan aturan hukum yang jelas agar BMT dapat berkembang sebagaimana konsep awal kemunculannya yang sangat ideal menggabungkan dua fungsi lembaga keuangan. Jangan sampai BMt kehilangan fungsi sosialnya sebagaimana realita di lapangan menunjukkan ada beberapa BMT yang bahkan sama sekali tidak mengelola dana sosial (Ismanto, 2015). Perlu ada koordinasi lintas lembaga untuk melakukan sinergi merancang aturan main bagi BMT agar tidak terjadi tumpang tindih tugas dan wewenang yang berakibat pada sulitnya BMT menjalankan usahanya.

\section{KESIMPULAN}

Undang-Undang nomor 1 tahun 2013 tentang Lembaga Keuangan Mikro memasukkan BMT dalam bagian dari lembaga keuangan mikro. Beberapa ketentuan dalam aturan tersebut berpengaruh terhadap fungsi sosial yang dijalankan oleh BMT yakni dalam hal status BMT itu sendiri, tumpang tindih lembaga yang mengawasi, pemisahan pengelolaan dana sosial, dan pembatasan wilayah usaha.

Ketentuan-ketentuan tersebut berpengaruh besar terhadap fungsi sosial yang dijalankan oleh BMT Dana Mentari Muhammadiyah Purwokerto. BMT Dana Mentari sampai dengan penelitian ini dilakukan belum sepenuhnya menyesuaikan dengan aturan perundangundangan terbaru. Pengaruh yang dirasakan pasca UU LKM yakni adanya pemisahan pengelolaan dana sosial dalam divisi terpisah yang menginduk pada lembaga, kerumitan dalam pelaporan kepada lembaga yang menaungi, serta kesulitan mengembangkan fungsi sosialnya akibat adanya image masyarakat bahwa BMT hanyalah lembaga keuangan komersial sebagaimana lainnya.

Terkait kesimpulan di atas, perlu adanya sosialisasi yang lebih massif oleh lembagalembaga yang memiliki wewenang terkait aturan perundang-undangan kepada BMT agar tidak terjadi tumpang tindih tugas, wewenang, dan tanggung jawab serta agar BMT tidak kebingungan dan kesulitan dalam menjalankan usaha dan melaporkannya. Di samping itu juga dibutuhkan sinergi antar BMT dalam komunitasnya untuk menghidupkan fungsi sosial yang diembannya agar status baitul maal yang diembannya dapat menjalankan misinya dengan baik.

\section{DAFTAR PUSTAKA}

Amalia, Euis. Keadilan Distributif dalam Ekonomi Islam; Penguatan Peran LKM dan UKM di Indonesia. Jakarta: Rajawali Pers, 2009. 
Huda, Nurul dan Mohamad Heykal. Lembaga Kenangan Islam Tinjanan Teoritis dan Praktis. Jakarta: Kencana, 2010.

Huda, Nurul, dkk. Baitul Maal Wa Tamwil, Sebuah Tinjanan Teoritis. Jakarta: AMZAH, 2016.

Ismanto, Kuat. "Pengelolaan Baitul Maal pada Baitul Maal wa Tamwil (BMT) di Kota Pekalongan”, Jurnal Penelitian, Vol 12 No. 1, Tahun 2015.

Khomsatun, "Sejarah Singkat BMT-KSU Dana Mentari Purwokerto", danamentaripurwokerto.blogspot.com, diakses pada 20 Juni 2021.

Masyitoh, Novita Dewi. “Analisis Normatif Undang-undang No. 1 Tahun 2013 Tentang Lembaga Keuangan Mikro (LKM) atas Status Badan Hukum dan Pengawasan Baitul Maal at Tamwil (BMT)", Jurnal Economica, Volume V, Edisi 2, Oktober 2014.

Murdiana, Elfa "Menggagas Payung Hukum Baitul Maal Wattanwil (BMT) Sebagai Koperasi Syariah dalam Bingkai Ius Constituendum", Jurnal Penelitian, Vol 10 No. 2, Tahun 2016.

Musobih, Fatkhul dan Safitri Mukarromah, "Tinjauan Syariah Terhadap Strategi Pemasaran Produk Akad Mudharabah di BMT Dana Mentari Karanglewas Purwokerto", Jurnal Hukum Ekonomi Syariah, Volume 2, Nomor 1, April 2019.

PKES, "Pusat Inkubasi Bisnis Usaha Kecil (PINBUK)" dalam www.ekonomisyariah.info. Diakses 1 Juli 2021.

Ridwan, Muhammad. Manajemen Baitul Maal Wal Tamwil. Yogyakarta: UII Press, 2004.

Rohmah, Umi “Konstruksi ldentitas Baitul Mal Wa Tamwil (BMT) Pasca UU No.1 Tahun 2013 Tentang Lembaga Keuangan Mikro, Istiqra', Volume 13 Nomor 02, Tahun 2014.

Salman, Kautsar Riza. Akutansi Perbankan Syariah Berbasis PSAK Syariah. Padang: Akademia Permata, 2012.

Saragih, Juli Panglima. Kebijakan Pengembangan Lembaga Keuangan Mikro: Urgensi dan Permasalahannya. Jakarta: Pusat Pengkajian, Pengelolaan Data dan Informasi (P3DI), SekJen DPR RI, 2011.

Satria, Awang Tri dkk. "Kajian Atas Fungsi Sosial Pada Tindakan Ekonomi Pelaku Lembaga Keuangan Mikro," Media Trend Vol. 10 No. 1 Maret 2015.

Soemitra, Andri .Bank dan Lembaga Keuangan Syariah. Jakarta: Kencana, 2012.

Suryabrata, Sumardi. Metode Penelitian. Jakarta: PT Raja Grafindo Persada, 2002.

Widodo, Hertanto et al. Panduan Praktis Operasional Baitul Mal Wat Tamwil (BMT). Bandung: Mizan, 1999.

Yunus, Jamal Lulail. Manajemen Bank Syariah. Malang: UIN- Malang Press: 2009.

\section{Aturan Perundang-undangan}


UU No 1 Tahun 2013 tentang Lembaga Keuangan Mikro.

UU No 25 tahun 1992 tentang Perkoperasian.

Keputusan Menteri Negara Koperasi dan Usaha Kecil dan Menengah nomor: 91/KEP/M.KUKM/IX/2004 tentang Petunjuk Pelaksanaan Kegiatan Usaha Koperasi Jasa Keuangan Syariah.

Peraturan OJK Nomor 13/POJK.05/2014 Tentang Penyelenggaraan Usaha Lembaga Keuangan Mikro.

\section{Dokumen dan wawancara}

Bagan struktur pengurus BMT Dana Mentari Muhammadiyah Purwokerto

Dokumen Standar Operasional Prosedur (SOP) BMT Dana Mentari Muhammadiyah Purwokerto.

Laporan Keuangan Baitul Maal Dana Mentari Muhammadiyah Purwokerto tahun 2020.

Endah Priatin (Manajer BMT dana Mentari Kantor Karanglewas), wawancara pada Juni-Juli 2021.

Budi Setiawan (Divisi Bitul Maal Dana Mentari), wawancara pada Juni-Juli 2021. 